\title{
TINDAK PIDANA PENGGUGURAN KANDUNGAN OLEH KORBAN PERKOSAAN DALAM PEMBAHARUAN HUKUM PIDANA INDONESIA
}

\author{
Kadek Jiyoti Mahayana, I Nyoman Putu Budiartha, I Made Minggu Widyantara \\ Fakultas Hukum Universitas Warmadewa, Denpasar-Bali, Indonesia
}

\begin{abstract}
Abstrak
Perlakuan aborsi merupakan suatu masalah yang sangat bertentangan dengan agama apapun dan undangundang di Indonesia. Namun diketahui terdapat pula pihak yang mendukung dan pihak yang menentang atas pengguguran kandungan, dimana sering menimpa wanita yang mengalami kehamilan akibat perkosaan, pasalnya wanita korban perkosaan yang melakukan pengguguran kandungam juga memerlukan perhatian akan kondisi psikologisnya yang mengalami trauma mengenai peristiwa yang telah menimpanya. Penelitian ini bertujuan untuk menelaah perlindungan hukum terhadap korban perkosaan yang melakukan pengguguran kandungan berdasarkan Kitab Undang-Undang Hukum Pidana dan menjelaskan tindak pidana pengguguaran kandungan oleh korban akibat perkosaan dalam pembaharuan kitab Undang-Undang Hukum Pidana. Jenis penelitian yang digunakan adalah penelitian hukum normatif dengan pendekatan konseptual. Sumber data hukum primer dan sekunder. Hasil penelitian menunjukkan bahwa pengayoman hukum terhadap korban perkosaan yang telah melakukan pengguguran kandungan dalam KUHP telah terabaikan dengan secara jelas melarang segala kegiatan aborsi baik atas permintaan wanita itu sendiri maupun dengan bantuan orang lain yang dijelaskan pada Pasal 346 sampai Pasal 349 KUHP tetapi terdapat pengecualian dimana wanita korban perkosaan yang melakukan pengguguran kandungan dimana dapat menyebabkan trauma psikologis yang pengaturannya tertuang pada undang-undang no. 36 Tahun 2009 Pasal 75 ayat (2). Dalam Pembaharuan Hukum Pidana Pengaturan aborsi diatur dalam Rancangan KUHP 2019 Bab XXI termasuk dalam tindak pidana terhadap nyawa bagian kedua tentang pengguguran kandungan pasal 470 sampai dengan pasal 472 RUUKUHP 2019.
\end{abstract}

Kata Kunci: Aborsi; Korban Perkosaan; Pembaharuan Hukum Pidana

\begin{abstract}
Abortion treatment is a problem that is contrary to any religion and the laws of Indonesia. However, it is known that there are also those who support and those who oppose abortion, which often happens to women who experience pregnancies as a result of rape, because women victims of rape who undergo abortion also need attention to their psychological conditions who are traumatized about the events that have happened to them. This study aims to examine the legal protection of rape victims who have aborted based on the Criminal Code and explain the criminal act of abusing the womb by victims of rape in the reform of the Criminal Code. This type of research is normative legal research with a conceptual approach. Primary and secondary legal data sources. The results of the study show that the legal protection of rape victims who have aborted their womb in the Criminal Code has been neglected by clearly prohibiting all abortion activities either at the request of the woman herself or with the help of others as described in Article 346 to Article 349 of the Criminal Code but there are exceptions where women rape victims who do abortions which can cause psychological trauma, the regulation of which is stipulated in law no. 36 of 2009 Article 75 paragraph (2). In the Criminal Law Reform Regulations on abortion are regulated in the Draft Criminal Code 2019, Chapter XXI, which is included in the second part of the crime against life regarding abortion, article 470 to article 472 of the 2019 RUUKUHP.
\end{abstract}

Keywords: Abortion; Rape Victim; Criminal Law Reform

\section{PENDAHULUAN}

Aborsi termasuk fenomena sosial yang semakin hari semakin menjadi perhatian. Pengguguran kandungan ialah dikeluarkannya bayi dalam kandungan seorang ibu sebelum waktunya (Soekidjo, 2010). Saat ini pengguguran kandungan tentunya sudah tidak asing lagi dibicarakan di kalangan masyarakat terutama di Kota-kota besar dan juga beberapa daerah di Indonesia. Tentunya pengguguran kandungan sudah menjadi peristiwa yang hampir sering terjadi bahkan oleh perempuan yang tidak mengharapkan kehamilan. Perlakuan aborsi merupakan sebuah solusi bagia kalangan masyarakata atas perlakuannya yang tidak berperi kemanusiaan, perkembangan jaman saat ini seiring 
berkembangnya teknologi yang mengakibatkan seluruh lapisan elemen masyarakat mengubah pola hidup dari tradisional ke pola hidup modren, tentu hal ini ada efek negatif dan positifnya. Maraknya pergaulan bebas akan mengakibatkan potensi melakukan seks bebas terutama dikalangan anak muda hal ini banyak kasus wanita hamil diluar nikah sah dihadapan adat dan agama sehingga solusi yang mereka tempuh adalah perlakuan aborsi. Pada umumnya dianggap oleh sebagian besar masyarakat adalah suatu tindak pidana, namun dalam hukum positif di Indonesia tindakan aborsi pada sebagian kasus tertentu terdapat pengecualian. Dalam KUHP aborsi itu dilarang sama sekali seperti yang telah dicantumkan dalam Pasal 299, 346 sampai pada Pasal 349, dimana ditegaskan bahwa aborsi dilarang untuk dilakukan dengan alasan apapun tanpa terkecuali. Akan tetapi dalam UU No.36 Tahun 2009 tentang Kesehatan disitu dikatakan terdapat pengecualian khususnya pada Pasal 75 ayat 2 dimana, aborsi dapat dilakukan bila terdapat indikasi kedaruratan medis dan aborsi karena kehamilan akibat perkosaan.

Tiap tahunnya, berjuta-juta perempuan Indonesia mengalami kehamilan yang tidak direncanakan, dan sebagian darinya memilih untuk mengakhiri kehamilan mereka dengan aborsi walaupun telah dilarang dengan tegas dalam undang-undang bahwa aborsi adalah tindakan legal (Tarore, 2013). Perlakuan aborsi merupakan tindakan yang melanggar hukum yaitu mengambil hak hidup terhadap calon bayi yang akan digugurkan, selanjutnya perlakuan aborsi dilarang oleh agama dan adat khususnya di Indonesia baik atas permintaan wanita itu sendiri maupun atas bantuan orang lain (Fidawaty, 2018). Beberapa contoh kasus pengguguran kandungan yang telah terjadi di wilayah Indonesia, yang pertama dilakukan oleh seorang remaja perempuan berusia 15 tahun di Jambi dengan inisial WA, yang kedua dilakukan oleh Reni dan dibantu Arin, warga Desa Catur, Kecamatan Sambi yang merupakan seorang bidan di sebuah rumah sakit swasta di Solo.

Jika dibandingkan KUHP dan RUU KUHP dengan Undang-Undang Kesehatan No.36 Tahun 2009, menampakkan adanya norma konflik (geschijld van normen) di dalam pengaturannya mengenai aborsi terdapat perbedaan diantara KUHP dan di dalam RUU KUHP dengan undang-undang No. 36 Tahun 2009 tentang Kesehatan Pasal 75 dan PP No. 61 tahun 2014 tentang kesehatan reproduksi Pasal 31 dalam mengatur masalah pengguguran kandungan. Dimana hal tersebut menunjukan pengguguran kandungan karena perkosaan yang diperbolehkan dan dapat dibenarkan atau dilindungi hukum, membandingkan dalam KUHP dan RUU KUHP 2019 tidak membenarkan atau mengijinkan seseorang untuk melakukan aborsi dengan alasan apapun juga.

Penelitian sebelumnya mengungkapkan bahwa ada Pengecuali mengenai legalisasi abortus provocatus sebagai bagian dari tindakan medis tertentu yang diizinkan dalam kasus adanya kompilasi yang mengancam jiwa ibu atau janin. Termasuk abortus provocatus yang diperkenankan pada korban perkosaan karena fisik maupun psikis korban yang tidak memungkinkan untuk mengandung, bahkan dikategorikan berbahaya akibat tindakan susila yang korban dapatkan (Zuhdi \& Handayani, 2013). Perlindungan terhadap perempuan korban kekerasan seksual sebagai pelaksana Abortus provokatus indikasi perkosaan adalah segala kegiatan untuk menjamin dan melindungi perempuan dan hakhaknya dalam hal keselamatan jiwa, reproduksi dan berpartisipasi secara optimal sesuai harkat dan martabat kemanusiaan, serta mendapat perlindungan dari kekerasan dan diskriminasi (H \& Nyoman Serikat P, 2017). Menurut Suputra \& Parwata, (2020) Tindak pidana aborsi diatur dalam pasal 346 sampai dengan pasal 349 KUHP yang menyatakan bahwa tindakan aborsi dilarang dengan alasan apapun, maka setiap orang yang melakukan aborsi maupun membantu proses tindakan aborsi dapat dipidana berdasarkan KUHP. Kemudian dilain sisi berdasarkan UU Kesehatan melarang pula tindakan aborsi, namun berdasarkan undang-undang tersebut terdapat pengkhususan yang tertuang dalam pasal 75 ayat (2) yang dalam rumusannya memberikan pengecualian apabila ada indikasi kedaruratan medis dan kehamilan karena korban perkosaan.

Dari beberapa kasus yang pernah terjadi seperti yang di paparkan pada latar belakang masalah, maka sangat pentingnya peraturan dan ketentuan hukum terhadap perlindungan hukum bagi mereka yang melakukan aborsi akibat kekerasan seksual atau perkosaan. Oleh sebab itu Penelitian ini bertujuan untuk menelaah perlindungan hukum terhadap korban perkosaan yang melakukan pengguguran kandungan berdasarkan Kitab Undang-Undang Hukum Pidana dan menjelaskan tindak Pidana pengguguaran kandungan oleh korban akibat perkosaan dalam pembaharuan kitab UndangUndang Hukum Pidana 


\section{METODE PENELITIAN}

Penelitian ini menggunakan penelitian hukum normatif yang meneliti bahan-bahan kepustakaan melalui pendekatan masalah pada perundang-undangan dan konseptual (Ahmad, 2008). Sumber data yaitu bahan hukum primer yaitu dengan mengkaji perundang- undangan serta keputusan-keputusan yang mengikat, sedangkan sumber data hukum sekunder memepedomani rancangan undang-undang, pendapat para pakar, hasil penelitian, serta jurnal-jurnal hukum dan juga internet yang ada kaitannya dengan materi penelitian ini, selanjutnay Sumber bahan hukum yang dipergunakan seperti kamus hukum dan ensiklopedia yang berkaitan dengan penelitian ini. Teknik pengumpulan bahan hukum yang dipergunakan dengan menelaah dan, mencatat, mengutip, meneliti data pustaka yang ada kaitannya dengan permasalahan yang dibahas. Analisis bahan hukum dengan teknik deskripsi, Teknik interprestasi, penerapan jenis-jenis penafsiran didalam ilmu hukum. Teknik argumentasi, pernyataan dari pemikiran atau analisis dari peneliti.

\section{HASIL DAN PEMBAHASAN}

\section{Perlindungan Hukum terhadap Korban Perkosaan y ang Melakukan Pengguguran Kandungan dalam KUHP}

Perlindungan Hukum ialah memberikan pelayanan terhadap masyarakat dimana kerugian orang lain dan diberikan terhadap masyarakat supaya nantinya masyarakat mendapatkan semua hak yang terdapat dalam hukum yang dimana ialah beberapa upaya-upaya penegakkan hukum agar dapat diberikan oleh aparat penegak hukum masyarakat mendapatkan rasa keamanan (Satjipto, 2000). Prinsip terhadap tindakan pemerintah dalam memberi pengayoman bersumber dari pengakuan yang bertumpu terhadap sejarah dari barat, konsep terhadap pengakuan dan pengayoman terhadap hak yang dimiliki oleh masyarakat mengarah terhadap pembatasan atau peletakan oleh masyarakat dan pemerintah

Pemerkosaan ialah tindakan yang kriminal terhadap seksual yang terjadi ketika seorang dengan paksa melakukan hubungan seksual baik adanya suatu paksaan atau dalam keadaan terancam. Aborsi terhadap Korban Perkosaan terhadap Jaminan Hak-Hak Reproduksi yang menjadi aspek dimana menyangkut kesehatan reproduksinya. Dalam Pasal 70 ayat (1) UU Kesehatan, kesehatan reproduksi merupakan keadaan sehat secara fisik, mental dan sosial secara utuh, yang terbebas oleh penyakit, fungsi, dan di dalam reproduksi pada pria dan wanita. Kesejahteraan dalam reproduksi yang dimana mengcakup kesejahteraan bereproduksi bagi perempuan. Undang-undang No. 26 Tahun 2000 terdapat pentingnya korban mendapatkan pengayoman dalam proses peradilan. Pada Pasal 34 ayat (1) dimana tertuang bahwa korban maupun saksi mempunyai hak atas perlindungan dari pengancaman, teror, tetapi tentunya dalam Undang-Undang yang mengkhususkan pengaturannya terhadap perlindungan korban dan sudah disahkan dimana masih sepenuhnya belum direalisasikan

Dalam perkara pidana, hukum yang berfokus dalam hak terhadap tersangka maupun terdakwa, sementara hak dapat diperoleh korban terabaikan, dalam pembahasan beracara pada hukum pidana khusus ada kaitannya terhadap hak masyarakat, lebih cenderung untuk mengupas hal-hal yang telah ada keterkaitan terhadap hak dengan pelaku tentunya belum adanya perhatian terhadap hak-hak yang dimiliki korban (Hamsah, 1986). Penting bagi korban untuk memperoleh pemulihan sebagaimana halnya upaya dalam penyeimbangan kondisi yang dialami korban dimana dapat mengalami gangguan-gangguan, yang tepatnya pengayoman terhadap korban. Dalam Hukum Pidana Positif masih diberlakukan, pengayoman terhadap korban masih dominan dalam pengayoman yang tidak tentu atau perlindungan yang belum langsung (Moerti, 2012).

Undang-Undang Nomor 36 Tahun 2009 masih memperbolehkan pengguguran kandungan akibat perkosaan tentunya terdapat syarat dimana dilakukan oleh tenaga yang kompeten. Dimana mengancam bahkan terdapat sanksi pidana, yang terdapat didalam hukum pidana dimana rumusan tersebut mengancam mereka yang melakukan aborsi Sedangkan di dalam KUHP tentunya masih belum memperdulikan alasan yang dilakukan. Jika abortus provocatus ialah pilihan dimana mesti harus ditempuh oleh korban perkosaan meskipun permintaan dirinya atau dibantu oleh orang lain atas persetujuan maupun tanpa disetujui oleh perempuan korban akibat perkosaan, dimana dengan dalam KUHP, perempuan tersebut tidak dapat lepas dari jeratan pidana. Pengguguran kandungan oleh seseorang korban akibat perkosaan dibolehkan apabila termuat di pasal 75 ayat (2) Undang- 
undang No. 36 Tahun 2009, kecuali atas indikasi kedaruratan medis atau atas dasar jaminan hak-hak reproduksinya

\section{Tindak Pidana Pengguguran Kandungan oleh Korban Perkosaan dalam Pembaharuan Kitab Undang-Undang Hukum Pidana}

Menimbang untuk terwujudnya hukum pidana nasional atas dasar Pancasila dan Undang-Undang Dasar Negara Republik Indonesia Tahun 1945, perlunya penyusunan hukum pidana nasional untuk memperbaharui KUHP yang diwariskan oleh pemerintah kolonial Hindia Belanda. Jika suatu negara hendak merepisi atau menyusun KUHP baru, dimana jalan yang paling mudah untuk dapat memperoleh data tentang asas, sistem Pidana modern dan rumusan delik adalah dengan membaca dan melakukan perbandingan kepada beberapa KUHP yang baru direvisi atau baru disusun (Hamsah, 1991). Dalam hal pengaturan pengguguran kandungan terdapat beberapa pengaturan yang saat ini berlaku di berbagai negara di dunia diantaranya hukum yang mengatur aborsi di Malaysia yang diatur didalam bagian kode pidana 312 tahun 1989. Hampir menyerupai Indonesia dimana pengguguran kandungan di Malaysia masih diperbolehkan, dimana terdapat ancaman terhadap nyawanya, didasari atas kesehatannya, maupun demi kesehatan mentalnya. Adapun hukum pengguguran kandungan di Singapura ialah diperbolehkan dan pengaturanya terdapat di Statuta Termination of Pregnancy Act. Peraturan ini mengatur bagaimana pengguguran kandungan diperbolehkan, oleh Warga Singapura ataupun pasangannya, penduduk asli dari Singapura. Pengguguran kandungan diperbolehkan apabila dilakukan terhadap perantau yang berada di Singapura tentunya mempunyai izin turis atau penduduk sosial, perempuan yang sudah tinggal empat bulan, pengguguran kandungan masih diperbolehkan apabila masa tinggalnya mengurangi ketentuan saat keselamatan ibunya dipertimbangkan, belum terdapat batasan umur untuk melakukan pengguguran kandungan, perempuan yang usianya masih enam belas tahun tetapi lebih dari empat belas tahun tidak diperlukan persetujuan dari orang tuanya untuk melakukan pengguguran kandungan, tetapi perempuan berusia 21 tahun atau lebih yang bisa pengguguran kandungan didasari keinginannya, tetapi pengguguran kandungan dilarang apabila usia kandungan sudah lebih dari enam bulan, terkecuali terdapat ancaman terhadap nyawa perempuan yang mengandung tersebut, perempuan di singapura yang ingin melakukan pengguguran kandungan harus terlebih dahulu berkonsul dengan dokter.

Pembaharuan dalam hukum di Indonesia dimana dimulainya undang-undang dasar 1945 tentunya tidak terlepas dari landasan dan tujuan yang tentunya ingin di capai sebagaimana dirumuskan di dalam pembukaan UUD 1945. Menurut Barda, (1996) Permasalahan hukum yang menyentuh aspek dalam kehidupan penduduk menyeluruh sehingga kapanpun dapat berubah dalam pembaharuan belum dapat dilaksanakan dengan seketika. Tentunya pembaharuan dalam pemidanaan terdapat pembaruan dalam substansi pemidanaan, pembaruan dalam struktur pemidanaan, dan pembaruan dalam pemidanaan ditinjau dalam aspek budaya. Bila dikaitkan dengan kasus pengguguran kandungan terdapat pada pembaharuan hukum pidana, didalam Rancangan UndangUndang KUHP 2019 tindak pidana aborsi terdapat dalam Bab XXI tentang Pengguguran Kandungan Bagian Kedua pada Pasal 470 sampai dengan Pasal 472. Rumusan Racangan Undang-undang KUHP 2019 bila dibandingkan dengan KUHP yang berlaku sekarang. Dalam Rancangan Undang-Undang KUHP 2019 seharusnya dapat memberikan harapan bagi ketidak selarasan norma yang tertuang dalam KUHP dan UU No. 36 tahun 2009 tentang Kesehatan, tetapi nyatanya Rancangan UU KUHP 2019 masih ada pertentangan antara RUU KUHP 2019 terhadap UU No. 36 tahun 2009 tentang Kesehatan.

Didalam rancangan UU KUHP 2019 baru terdapat dampak adanya pembatasan ruang gerak tenaga kesehatan dalam upaya untuk memberikan pertolongan terhadap perempuan yang menggugurkan kandungan akibat perkosaan dan terdapat unsur kedaruratan medisialis bilamana sebenarnya masih diperboleh oleh UU No. 36 tahun 2009 tentang Kesehatan tetapi dikarenakan takut terpidana membuat mereka menolak untuk memberikan informasi atau layanan mengenai aborsi, berdasarka RUU KUHP 2019 terdapat pengecualian dimana terbatas hanya kepada dokter yang tertuang dalam ketentuan Pasal 472 ayat (3) dimana ketentuan tersebut belum sesuai terhadap Pasal 75 ayat (3) UU No. 36 tahun 2009 tentang Kesehatan dimana menyatakan bahwa aborsi diperbolehkan apabila sudah menanyakan terhadap konselor yang berwenang, tetapi dalam Pasal 470 dan 471 RUU KUHP masih dengan tegas mempidana perempuan yang melakukan pengguguran 
kandungan meski dalam keadaan aborsi medisialis. Dalam RUU KUHP 2019 masih tidak menaruh perhatian pada aborsi atas kehamilan akibat perkosaan ditunjukan dengan mempersempit ruang gerak tenaga kesehatan itu sendiri dimana dapat menimbulkan potensi yang besar terhadap perempuan yang ingin melakukan pengguguran kandungan dimana membahayakan jiwanya yang dilakukan secara belum aman.

\section{SIMPULAN DAN SARAN}

1. Simpulan

Berdasrkan hasil analisis data diketahui bahwa regulasi terhadap pengguguran kandungan dilakukan oleh keinginan perempuan tersebut didalam KUHP pengaturannya terdapat dalam Bab 19 Pasal 346 sampai dengan Pasal 349, dan digolongkan ke dalam kejahatan terhadap nyawa. Pengaturan terhadap tindak pidana pengguguran kandungan pengaturannya terdapat pada Pasal 346 Kitab Undang-Undang Hukum Pidana sampai dengan Pasal 349 Kitab Undang-Undang Hukum Pidana dimana dinyatakan bahwa tindakan aborsi dilarang menurut KUHP tanpa terkecuali, tetapi UU No. 36 Tahun 2009 Pasal 75 ayat (2) tercantum pengecualian dimana perempuan melakukan pengguguran kandungan karena kandungan tersebut diakibatkan oleh perkosaan yang dapat menyebabkan trauma psikologis terhadap perempuan korban perkosaan tersebut, yang kedua tindak pidana pengguguran kandungan oleh korban perkosaan yang ada didalam pembaruan hukum pidana pengaturannya tertuang dalam Rancangan Undang-undang KUHP) Tahun 2019 tertuang dalam Pasal 470 sampai Pasal 472 Bab XXI mengenai tindak pidana terhadap nyawa dan bagian kedua tentang pengguguran kandungan, tetapi rumusan pada pasal mengenai aborsi dalam Rancangan Undangundang KUHP 2019 bertentangan dengan Peraturan Perundang-undangan yang melegalkan kegiatan pengguguran kandungan korban akibat perkosaan dimana didalam Peraturan Pemerintah No. 61 Tahun 2014 tentang Kesehatan Reproduksi, Undang-undang No. 36 Tahun 2009 tentang Kesehatan.

\section{Saran}

Dari hasil penelitian di atas, adapun yang menjadi saran yaitu bagi pemerintah hendaknya agar memperjelas pengaturan pengguguran kandungan yang menimpa korban akibat perkosaan yang menggugurkan kandungan yang terkandung di dalam KUHP yang masih berlaku sekarang, dalam perumusan RUU KUHP 2019 dan kedepannya agar memperhatikan dampak yang akan timbul serta lebih mensinkronkan terhadap perlindungan terhadap korban perkosaan bilamana melakukan aborsi yang pengaturannya terdapat pada UU Kesehatan No.36 Tahun 2009 dan perlindungan terhadap hakhak reproduksi yang tertuang pada Peraturan Pemerintah No. 61 Tahun 2014 tentang Kesehatan Reproduksi, yang kedua bagi masyarakat agar lebih meningkatkan ilmu pengetahuannya dengan memperbaharui cara pemahaman mengenai informasi tentang pembaharuan yang di lakukan oleh pemerintah agar mudah dimengerti dan dapat pahami. Diharapkan masyarakat semakin paham mengenai perlindungan yang tertuang pada Undang-undang Kesehatan No. 36 Tahun 2009 dan perlindungan terhadap hak-hak reproduksi yang di atur pada Kesehatan Reproduksi pada Peraturan Pemerintah No. 6. Tahun 2014 memiliki kekuatan hukum pada proses peradilan dimuka persidangan.

\section{DAFTAR PUSTAKA}

Ahmad, B. (2008). Metode Penelitian Hukum. Pustakasetia.

Barda, N. A. (1996). Kebijakan Hukum Legislatif dalam Penanggulangan Kejahatan dengan Pidana Penjara. Universitas Diponogoro.

Fidawaty, L. (2018). Aborsi dalam Perspektif Hak Asasi Manusia dan Hukum Islam (Analisis terhadap Peraturan Pemerintah No. 61 tahun 2014 tentang Kesehatan Reproduksi). Al-'Adalah, 14(1), 107-130.

H, R. E., \& Nyoman Serikat P, A. . E. S. A. (2017). Perlindungan Hukum Terhadap Perempuan Korban Kekerasan Seksual Sebagai Pelaku Abortus Provokatus Indikasi Perkosaan. Jurnal Law, 6(1), 1-13.

Hamsah, A. (1986). Perlindungan Terhadap Hak-hak Asasi Manusia. Bina cipta.

Hamsah, A. (1991). Perbandingan Dalam Hukum Pidana Beberapa Negara. Sinar Grafika.

Moerti, H. S. (2012). Kekerasan dalam Rumah Tangga dalam Perspektif Yuridis Viktimologis. Sinar Garfika.

Satjipto, R. (2000). Ilmu Hukum. Citra Aditya Bakti.

Soekidjo, N. (2010). Ilmu Perilaku Kesehatan. Rineka Cipta.

Suputra, I. B. M. A., \& Parwata, I. G. N. (2020). Pengaturan Tindak Pidana Aborsi dalam KUHP dan UU No. 36 Tahun 2009 tentang Kesehatan. 9(12), 1-11. 
Jurnal Konstruksi Hukum

Vol. 2, No. 1, 2021

Tarore, F. B. J. (2013). Pengguguran Kandungan Akibat Pemerkosaan dalam KUHP. 2(2), 30-42.

Zuhdi, M., \& Handayani, I. N. (2013). Perundang-Undangan di Indonesia Terkait Hak Fungsi Reproduksi Korban Perkosaan. Recidive, 2(2), 185-192. 